\title{
Penularan Fitoplasma Sapu pada Tanaman Kacang Tanah oleh Serangga Vektor Orosius argentatus dan Deteksi Molekuler dengan Teknik PCR
}

\author{
Transsmission of Peanut Witches Broom Phytoplasma by \\ Insect Vector Orosius argentatus and \\ Its Molecular Detection using PCR Technique
}

\author{
Tatit Sastrini, Kikin Hamzah Mutaqin* \\ Institut Pertanian Bogor, Bogor 16680
}

\begin{abstract}
ABSTRAK
Penyakit sapu yang disebabkan oleh fitoplasma dapat menyebabkan kehilangan hasil yang nyata pada kacang tanah (Arachis hypogaea). Penularan fitoplasma yang paling utama di lapangan ialah melalui serangga vektor. Penelitian ini bertujuan menentukan potensi wereng daun yang berada di pertanaman kacang tanah dalam menularkan fitoplasma dan sifat penularannya. Vektor wereng daun Orosius argentatus dan Empoasca sp. dipilih sebagai serangga uji. Metode yang digunakan meliputi uji hayati penularan fitoplasma masing-masing oleh O. argentatus dan Empoasca sp. (keduanya tergolong serangga Ordo Hemiptera, Famili Cicadellidae) dan mendeteksi fitoplasma dengan teknik PCR untuk mengonfirmasi asosiasi antara penyebab penyakit sapu (fitoplasma), vektor, dan gejala penyakit yang muncul pada tanaman. Hasil penelitian menunjukkan bahwa gejala penyakit sudah muncul pada perlakuan menggunakan serangga penular $O$. argentatus 1 ekor per tanaman, sedangkan Empoasca sp. bukan merupakan vektor dari fitoplasma. Masa inkubasi fitoplasma pada inang semakin singkat dengan semakin banyaknya jumlah $O$. argentatus yang diberikan. Fitoplasma terdeteksi dengan teknik PCR menggunakan pasangan primer $\mathrm{P} 1 / \mathrm{P} 7$ pada contoh tanaman yang bergejala dan tubuh wereng $O$. argentatus penularnya.
\end{abstract}

Kata kunci: Empoasca sp., polymerase chain reaction, wereng daun

\begin{abstract}
Witches' broom disease caused by phytoplasma is a very serious disease on peanut (Arachis hypogaea) which may potentially lead to high yield loss. Insects are the most important agents of phytoplasma transmission in the field. The objective of this research was to examine the potential role of leafhoppers species as insect vector of phytoplasma and to determine their transmission characteristic. Two species of leafhopper i.e. O. argentatus and Empoasca sp. (both belong to Hemiptera: Cicadellidae) were chosen for this study. The methodology involved were transmission study of phytoplasma by $O$. argentatus and Empoasca sp., and molecular detection of phytoplasma by PCR technique to confirm the association of pathogen, insect vector and symptomatic plants. The result showed that specific symptom was observed when using $O$. argentatus in the transmission study with number of insect as low as 1 insect per plant, whereas Empoasca sp. was not able to transmit the disease. Incubation period of phytoplasma in the host plant was affected by the number of insect, i.e. the more insect vector the shortest incubation period. The phytoplasma was successfully detected using P1/P7 primer in symptomatic plants as well as in the insect vector.
\end{abstract}

Key words: Empoasca sp., leafhoppers, polymerase chain reaction

*Alamat penulis korespondensi: Departemen Proteksi Tanaman, Fakultas Pertanian, Institut Pertanian Bogor, Kampus Darmaga, Jalan Kamper, Bogor 16680.

Tel: 0251-8629364, Faks: 0251-8629362, Surel: kikinhm@yahoo.com 


\section{PENDAHULUAN}

Fitoplasma telah dilaporkan sebagai penyebab penyakit penting pada beberapa tanaman pertanian (Wongkaew dan Fletcher 2004). Penyakit sapu yang disebabkan oleh fitoplasma merupakan salah satu penyakit penting pada pertanaman kacang tanah di Indonesia yang dapat menjadi salah satu penyebab rendahnya produktivitas kacang tanah dalam negeri. Menurut Nugroho (2000) penyakit sapu (witches' broom) dapat menurunkan bobot polong dari $41 \%$ sampai $100 \%$. Sejauh ini, belum ada cara pengendalian yang efektif untuk fitoplasma penyebab penyakit sapu pada kacang tanah di lapangan.

Penularan fitoplasma dapat melalui serangga vektor, tali putri, dan penyambungan (D'Arcy dan Nault 1982; Weintraub dan Beanland 2006; Bertaccini dan Duduk 2009; Přibylová dan Špak 2013). Serangga vektor adalah agens penular utama fitoplasma di lapangan. Di Pulau Jawa, Sumatera, dan Sulawesi Orosius argentatus (Hemiptera: Ciccadellidae) menjadi vektor penyakit sapu pada beberapa tanaman kacang-kacangan, termasuk pada tanaman kacang tanah. Spesies lain dari famili Ciccadellidae ialah Empoasca sp. yang dilaporkan menjadi vektor fitoplasma penyebab penyakit sapu pada kacang gude (Cajanus cajan) di Florida (McCoy et al. 1983), namun belum dilaporkan sebagai vektor fitoplasma pada kacang tanah. Informasi dan pemahaman tentang jenis-jenis serangga vektor, sifat-sifat penularan fitoplasma oleh vektor, dan identitas patogennya baik menggunakan pendekatan konvensional maupun molekul merupakan dasar yang penting untuk penyusunan strategi pengendalian yang efektif.

Penelitian inibertujuanmenentukan potensi wereng daun yang berada di pertanaman kacang tanah dalam menularkan fitoplasma dan memperoleh informasi tentang sifat vektor terkait penularan serta pengaruhnya terhadap masa inkubasi penyakit dan kejadian penyakit pada kacang tanah.

\section{BAHAN DAN METODE}

\section{Seleksi dan Pemeliharaan Wereng Daun}

Wereng daun yang digunakan dalam uji penularan fitoplasma berasal dari pertanaman kacang tanah di sekitar kampus IPB Darmaga. Berdasarkan pengamatan dan pengambilan contoh, diperoleh beberapa jenis wereng daun. Hanya dua spesies wereng daun, yaitu O. argentatus dan Empoasca sp. (Gambar 1), yang populasinya paling tinggi di pertanaman serta mampu bertahan hidup dan berkembang biak setelah melalui proses pemeliharaan di dalam kurungan dengan inang tanaman kacang tanah. Hal ini menunjukkan bahwa tanaman kacang tanah merupakan inang bagi kedua jenis wereng daun tersebut. Perbanyakan wereng daun di laboratorium dilakukan untuk menghasilkan keturunan yang bebas fitoplasma atau patogen lainnya.

\section{Penyiapan Tanaman dan Sumber Inokulum}

Tanaman kacang tanah varietas Garuda sehat berumur 2 minggu diperoleh dari hasil penanaman sendiri. Tanaman kacang tanah bergejala penyakit sapu digunakan sebagai sumber inokulum. Tanaman tersebut diperoleh dari lahan kacang tanah di sekitar wilayah kampus IPB Darmaga. Tanaman dipelihara pada medium tanam campuran tanah dan pupuk kandang (2:1) pada pot ukuran $19 \mathrm{~cm} \times 14 \mathrm{~cm}$, kemudian diberi kurungan kasa berukuran $150 \mathrm{~cm}$ x $40 \mathrm{~cm}$ x $60 \mathrm{~cm}$.

\section{Uji Penularan Fitoplasma Menggunakan Wereng Daun}

Bagian daun yang menunjukkan gejala penyakit sapu disungkup menggunakan kurungan (diameter $6 \mathrm{~cm}$ dan tinggi $12 \mathrm{~cm}$ ), imago wereng daun $O$. argentatus dan Empoasca sp. generasi ke-2 yang dipelihara dan dibiakkan pada kurungan di laboratorium, dimasukkan ke dalam kurungan tersebut untuk melakukan periode makan akuisisi selama 3 hari pada tanaman sumber inokulum.

Tiga daun teratas tanaman kacang tanah sehat berumur 2 minggu disungkup menggunakan kurungan (diameter $6 \mathrm{~cm}$ dan tinggi 
$12 \mathrm{~cm}$ ), wereng daun dengan jumlah masingmasing 1, 3, 5, dan 7 ekor per tanaman dimasukkan ke dalamnya untuk melakukan periode laten sekaligus periode makan inokulasi selama 3 hari. Periode makan akuisisi perlakuan kontrol menggunakan tanaman kacang tanah sehat dengan jumlah $O$. argentatus dan Empoasca sp. masing-masing 3 ekor per tanaman. Peubah pengamatan dalam penelitian ini ialah masa inkubasi penyakit dan kejadian penyakit (KP) yang dihitung berdasarkan pada:

$$
\mathrm{KP}=\mathrm{n} / \mathrm{N} \times 100 \% \text {, dengan }
$$

$\mathrm{n}$, jumlah tanaman bergejala; $\mathrm{N}$, total jumlah tanaman uji.

\section{Rancangan Percobaan dan Analisis Data}

Percobaan untuk uji penularan fitoplasma dirancang dengan rancangan acak lengkap yang terdiri atas 10 taraf perlakuan, yaitu penularan masing-masing dengan wereng daun $O$. argentatus dan Empoasca sp. 1, 3, 5, dan 7 per tanaman, serta perlakuan kontrol. Jumlah ulangan setiap perlakuan adalah 3 tanaman. Data dianalisis dengan program statistical analysis system versi 9.1.3 untuk Windows. Perlakuan yang berpengaruh nyata diuji lanjut dengan uji Duncan pada taraf nyata $\alpha 0.05$.

\section{Deteksi Fitoplasma Menggunakan Teknik PCR}

Deteksi fitoplasma menggunakan teknik polymerase chain reaction (PCR) terdiri atas tahapan ekstraksi DNA total, amplifikasi, dan visualisasi hasil (PCR).

\section{Ekstraksi DNA Total}

Ekstraksi DNA Total Tanaman. Ekstraksi DNA total dari tanaman dilakukan terhadap semua ulangan pada setiap perlakuan uji penularan yang dijadikan satu contoh komposit dan pada tanaman sumber inokulum. Sampel daun diambil saat tanaman menunjukkan gejala awal penyakit (pemendekan ruas daun dan terbentuknya daun-daun baru yang berukuran lebih kecil daripada kondisi normal). Ekstraksi DNA dilakukan dengan menggunakan metode
Dellaporta (1983) yang dimodifikasi, yaitu sebanyak $0.15 \mathrm{~g}$ contoh daun digerus dengan pistil yang berisi $1.5 \mathrm{~mL}$ bufer ekstraksi fitoplasma dingin $\left(\mathrm{K}_{2} \mathrm{HPO}_{4} \cdot 3 \mathrm{H}_{2} \mathrm{O}, \mathrm{KH}_{2} \mathrm{PO}_{4}\right.$, sukrosa, polyvinylpyrrolidone/PVP-10). Hasil gerusan dipindah ke dalam tabung mikro $2 \mathrm{~mL}$ dan disentrifugasi pada kecepatan 3000 x g (HettichMikro200R Centrifuge) selama 3 menit pada suhu $4{ }^{\circ} \mathrm{C}$. Supernatan disentrifugasi $12000 \mathrm{x}$ g selama 25 menit pada suhu $4{ }^{\circ} \mathrm{C}$. Endapan yang terbentuk diresuspensi dengan $0.75 \mathrm{~mL}$ bufer CTAB suhu $60{ }^{\circ} \mathrm{C}$ dan diinkubasi 15 menit, pada suhu $60{ }^{\circ} \mathrm{C}$. Ke dalam suspensi, ditambahkan $0.75 \mathrm{~mL}$ kloroform/isoamil alkohol $(24: 1 \mathrm{v} / \mathrm{v})$. Suspensi disentrifugasi pada $13000 \mathrm{x}$ g selama 5 menit. Lapisan epifase dipindahkan ke tabung mikro baru, kemudian dipresipitasi dengan isopropanol $\left(-20^{\circ} \mathrm{C}\right)$ dengan volume setara, tabung dibolak-balik beberapa kali. Inkubasi dilakukan pada suhu $-20{ }^{\circ} \mathrm{C}$, selama 30 menit. Suspensi disentrifugasi pada $13000 \mathrm{x}$ g, selama 5 menit, pada suhu $4{ }^{\circ} \mathrm{C}$. Supernatan dibuang, endapan yang dihasilkan dicuci dua kali dengan $200 \mu \mathrm{L}$ etanol $70 \%$ dingin $\left(-20{ }^{\circ} \mathrm{C}\right)$. Endapan DNA diresuspensikan dengan bufer TE sebanyak $25 \mu \mathrm{L}$.

\section{Ekstraksi DNA Total Wereng Daun.} Ekstraksi DNA total dari wereng daun dilakukan dengan metode Goodwin et al. (1994). Wereng dari setiap perlakuan yang telah melakukan periode inokulasi dikeluarkan dari kurungan dan dikumpulkan menjadi satu contoh komposit kemudian 3 ekor wereng dari masing-masing perlakuan diambil secara acak untuk ekstraksi DNA total. Wereng digerus menggunakan mikropistil dalam tabung mikro berisi $125 \mu \mathrm{L}$ bufer CTAB dengan sedikit serbuk kaca. Suspensi hasil gerusan dikocok, kemudian diinkubasi pada suhu $65^{\circ} \mathrm{C}$ selama 5 menit. Ke dalam suspensi, ditambahkan campuran larutan kloroform:isoamil alkohol $(24: 1 \mathrm{v} / \mathrm{v})$ dengan volume setara dengan suspensi yang diperoleh. Suspensi diinkubasi pada suhu kamar selama 20 menit, kemudian disentrifugasi pada kecepatan $10000 \mathrm{x}$ g selama 10 menit. Sebanyak $90 \mu \mathrm{L}$ supernatan dipindahkan ke dalam tabung mikro baru, 
kemudian DNA dipresipitasi dengan $10 \mu \mathrm{L}$ $\mathrm{NaOAc} 3 \mathrm{M}$ pH 5.2 dan $250 \mu \mathrm{L}$ etanol absolut $\left(-20{ }^{\circ} \mathrm{C}\right)$ dan diinkubasi pada suhu $-20{ }^{\circ} \mathrm{C}$ selama 30 menit. Suspensi disentrifugasi pada $12000 \mathrm{x}$ g selama 15 menit. Supernatan dibuang, endapan yang dihasilkan dicuci 2 kali dengan $200 \mu \mathrm{L}$ etanol $70 \%\left(-20^{\circ} \mathrm{C}\right)$. Endapan DNA diresuspensikan dengan $50 \mu \mathrm{L}$ bufer.

Deteksi Fitoplasma Menggunakan Teknik PCR. Deteksi fitoplasma dengan teknik PCR dilakukan untuk seluruh contoh DNA total yang diekstraksi dari tanaman sakit dari lapangan, tanaman uji hasil penularan dan wereng daun uji. DNA contoh hasil ekstraksi diamplifikasi dengan teknik PCR menggunakan mesin PCR (GeneAmp PCR System 9700) dengan sepasang primer oligonukleotida, yaitu P1 (5'AAG AGT TTG ATC CTG GCT CAG GAT 3') (Deng dan Hiruki 1991) dan P7 (5'CGT CCT TCATCG GCT CCT 3') (Schneider et al. 1995) yang mampu mengamplifikasi sekuen DNA pada daerah seluruh gen 16S, spacer region, dan pangkal gen $23 \mathrm{~S}$ rDNA dari umumnya fitoplasma dengan ukuran $1800 \mathrm{pb}$ (Smart et al. 1996). Reaksi PCR dilakukan pada volume total $25 \mu \mathrm{L}$, terdiri atas $1 \mu \mathrm{L}$ cetakan DNA (DNA template), $12.5 \mu \mathrm{L} 2 \mathrm{X}$ KAPA2G Fast ReadyMix, $9.5 \mu \mathrm{L}$ ddH2O, $1 \mu \mathrm{L}$ primer forward $(5 \mathrm{pmol})$, dan $1 \mu \mathrm{L}$ primer reverse (5 pmol). Proses PCR meliputi denaturasi awal pada $92{ }^{\circ} \mathrm{C}, 1$ menit; 35 kali siklus denaturasi pada $95{ }^{\circ} \mathrm{C}, 1$ menit, annealing pada $55^{\circ} \mathrm{C}$, 1 menit, dan ekstensi pada $72{ }^{\circ} \mathrm{C}, 1.5$ menit; dan ekstensi akhir pada suhu $72{ }^{\circ} \mathrm{C}, 10$ menit.

\section{Visualisasi DNA Hasil Amplifikasi PCR dengan Elektroforesis Gel Agarosa}

DNA hasil ekstraksi maupun PCR dielektroforesis dengan gel agarosa $1 \%$ dalam $2 \mathrm{X}$ bufer TAE yang mengandung etidium bromida pada 75 volt selama 35 menit. Hasil elektroforesis divisualisasi pada transiluminator UV untuk mengamati pita DNA yang terbentuk dan difoto dengan kamera digital yang dilengkapi filter oranye.

\section{HASIL}

\section{Uji Penularan Fitoplasma Menggunakan Wereng Daun}

Kejadian Penyakit dan Masa Inkubasi Fitoplasma. Penularan fitoplasma dengan wereng daun $O$. argentatus menunjukkan hasil positif untuk semua perlakuan dengan kejadian penyakit $100 \%$, kecuali pada perlakuan kontrol. Masa inkubasi fitoplasma berkisar dari 21 sampai 67 hari (Tabel 1).

Gejala Penyakit Sapu. Tanaman uji hasil penularan dengan Empoasca sp. tidak menunjukkan gejala penyakit sapu. Perlakuan uji penularan fitoplasma dengan wereng daun $O$. argentatus dengan jumlah serangga 1, 3, dan 5 ekor per tanaman menimbulkan gejala berupa pembentukan daun-daun baru yang berukuran lebih kecil dan pemendekan ruas daun, sedangkan pada perlakuan dengan 7 ekor $O$. argentatus per tanaman gejala yang muncul berkembang sampai gejala lanjut dan menunjukkan gejala khas dari penyakit sapu berupa ginofor mengarah ke atas (geotrofisme negatif) yang menyebabkan tidak terjadinya pembentukan polong, pembentukan tunastunas samping dengan daun yang kecil, dan pembentukan struktur filodi (Gambar 2).

\section{Deteksi Fitoplasma Menggunakan Teknik}

PCR. Hasil uji penularan dan deteksi fitoplasma menggunakan teknik PCR pada tanaman kontrol dan serangga yang digunakan untuk penularan menunjukkan hasil yang negatif. Hal ini menunjukkan bahwa tanaman kacang tanah sehat dan wereng daun yang digunakan untuk percobaan bebas dari fitoplasma.

Fitoplasma terdeteksi pada contoh tanaman kacang tanah hasil penularan dengan $O$. argentatus yang sebelumnya telah melakukan periode akuisisi pada tanaman sumber inokulum dan pada wereng daun yang digunakan untuk penularannya. Fitoplasma tidak terdeteksi pada contoh tanaman kacang 
Tabel 1 Kejadian penyakit dan masa inkubasi fitoplasma pada uji penularan dengan wereng daun Orosius argentatus dan Empoasca sp.

\begin{tabular}{|c|c|c|c|c|}
\hline \multirow{2}{*}{ Serangga vektor } & \multirow{2}{*}{$\begin{array}{l}\text { Jumlah vektor } \\
\text { (ekor) }\end{array}$} & \multicolumn{2}{|c|}{ Kejadian penyakit } & \multirow{2}{*}{$\begin{array}{l}\text { Masa inkubasi } \\
\text { (HSP) }\end{array}$} \\
\hline & & Gejala/ulangan & Persentase & \\
\hline Orosius & Kontrol & $0 / 3$ & 0 & $-{ }^{a}$ \\
\hline \multirow[t]{4}{*}{ argentatus } & 1 & $3 / 3$ & 100 & $67.33 \mathrm{a}$ \\
\hline & 3 & $3 / 3$ & 100 & $61.33 \mathrm{a}$ \\
\hline & 5 & $3 / 3$ & 100 & $53.33 \mathrm{a}$ \\
\hline & 7 & $3 / 3$ & 100 & $21.33 \mathrm{~b}$ \\
\hline \multirow{5}{*}{ Empoasca sp. } & Kontrol & $0 / 3$ & 0 & - \\
\hline & 1 & $0 / 3$ & 0 & - \\
\hline & 3 & $0 / 3$ & 0 & - \\
\hline & 5 & $0 / 3$ & 0 & - \\
\hline & 7 & $0 / 3$ & 0 & - \\
\hline
\end{tabular}

${ }^{a}$ Tanaman uji tidak menunjukkan gejala sampai akhir pengamatan

Nilai rataan pada kolom yang diikuti oleh huruf yang berbeda menunjukkan perbedaan nyata dengan uji selang berganda Duncan $\alpha 0.05$

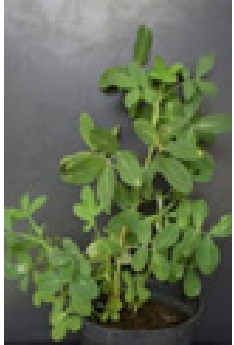

a

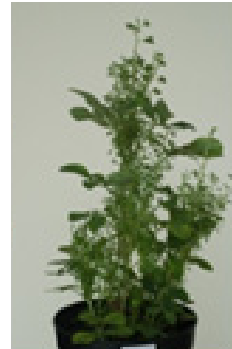

$\mathrm{b}$

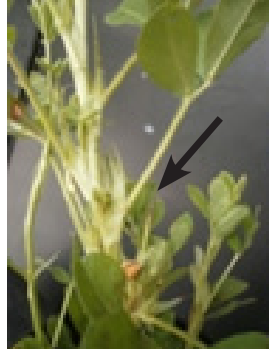

c

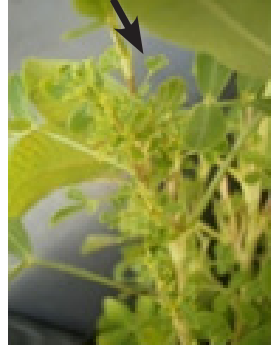

d

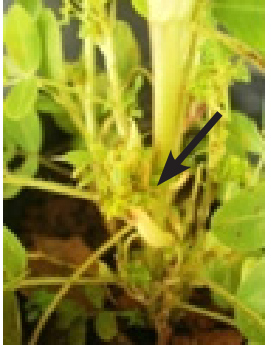

e

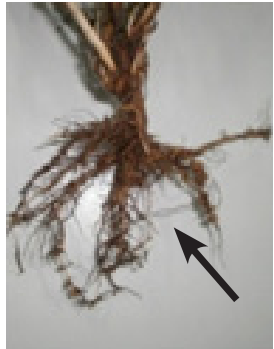

$\mathrm{f}$

Gambar 2 Gejala penyakit sapu kacang tanah hasil penularan fitoplasma menggunakan Orosius argentatus. a, Tanaman kontrol; b, Tanaman menunjukkan gejala penyakit sapu; c, Ginofor mengarah ke atas (geotrofisme negatif); d, Pembentukan tunas-tunas samping dengan daun yang kecil; e, Pembentukan struktur filodi; dan f, Tidak terbentuknya polong.

tanah hasil penularan dengan Empoasca sp. maupun pada tubuh wereng Empoasca sp. yang digunakan untuk penularan (Tabel 2). Hasil deteksi dengan teknik PCR yang positif ditandai dengan terbentuknya pita DNA berukuran 1800 pb (Gambar 3).

\section{PEMBAHASAN}

Pengukuran kejadian penyakit menunjukkan bahwa $O$. argentatus merupakan vektor yang efektif menularkan fitoplasma. Jumlah vektor berbanding terbalik dengan masa inkubasi. Hal ini terjadi karena pengaruh dari jumlah inokulum yang ditularkan ke dalam jaringan tanaman oleh vektor. Gejala yang teramati pada perlakuan uji penularan fitoplasma dengan wereng daun $O$. argentatus dengan jumlah serangga 1,3 , dan 5 ekor per tanaman tidak menimbulkan gejala lebih lanjut, seperti pada perlakuan 7 ekor per tanaman (Gambar 2). Hal ini kemungkinan juga terjadi karena jumlah fitoplasma yang ditularkan tidak mendukung untuk meningkatkan keparahan penyakit. Penyebaran dan perkembangan penyakit tanaman dipengaruhi oleh kepadatan inokulum yang ditularkan oleh aktivitas vektor serta kemampuan fitoplasma dalam proses sirkulasi dan berkembang biak pada tubuh vektor (D’Arcy dan Nault 1982; Weintraub 2007).

Menurut Iwaki et al. (1978) periode makan akuisisi minimum dari $O$. argentatus adalah 1 hari, periode makan inokulasi minimum 1 jam, dan periode laten fitoplasma 
Tabel 2 Hasil deteksi fitoplasma pada contoh wereng dan tanaman uji dengan teknik PCR

\begin{tabular}{lccc}
\hline Jenis vektor & $\begin{array}{c}\text { Jumlah vektor } \\
\text { (ekor) }\end{array}$ & Tanaman & Hasil PCR \\
\hline Orosius & Kontrol & - & Wereng \\
argentatus & 1 & + & - \\
& 3 & + & + \\
Empoasca sp. & 5 & + & + \\
& 7 & + & + \\
& Kontrol & - & - \\
& 1 & - & - \\
& 3 & - & - \\
\hline
\end{tabular}

+, DNA fitoplasma positif teramplifikasi; -, DNA fitoplasma tidak teramplifikasi.

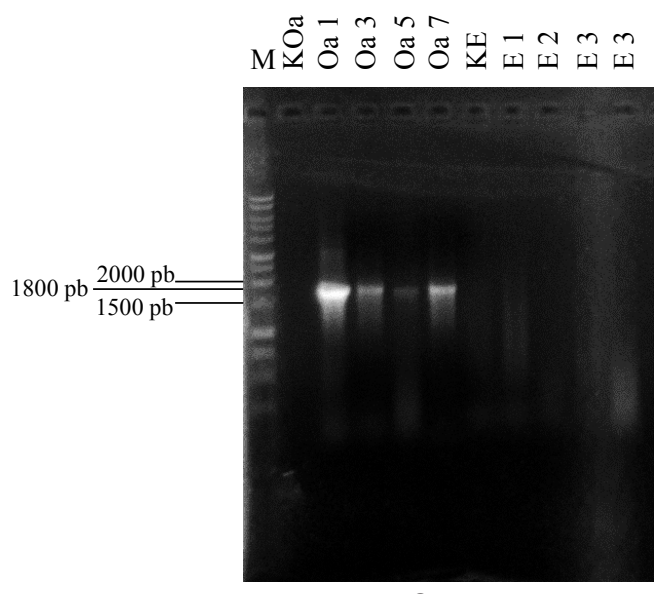

a

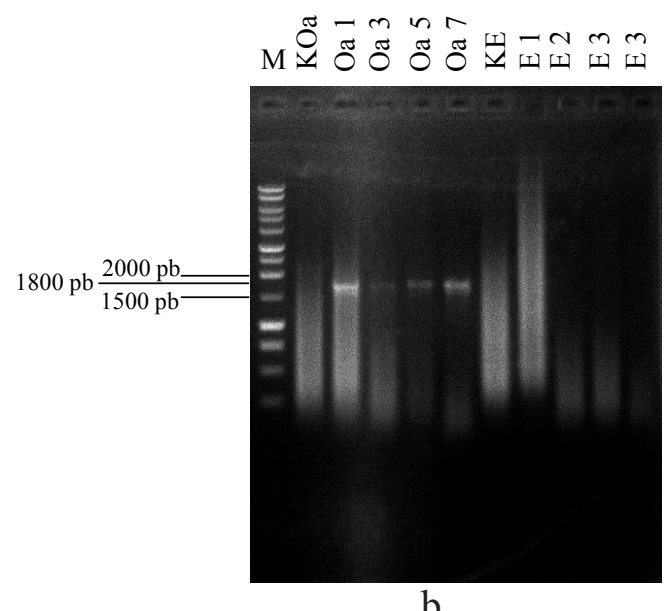

b

Gambar 3 Hasil deteksi fitoplasma dengan teknik PCR untuk berbagai contoh tanaman dan wereng daun. a, Contoh tanaman kacang tanah hasil uji penularan fitoplasma; b, Contoh wereng daun yang digunakan pada uji penularan fitoplasma; M, 1 kb ladder; K, Kontrol; Oa, Orosius argentatus; E, Empoasca sp.; 1,3,5,7, jumlah wereng daun.

dalam tubuh vektor sekitar 20-26 hari, dan serangga yang telah mengandung fitoplasma dapat menularkan sampai akhir masa hidupnya. Deteksi molekuler terhadap keberadaan fitoplasma pada contoh jaringan tanaman kacang tanah dan tubuh wereng pada uji penularan penting dilakukan untuk mengklarifikasi asosiasi antara penyebab penyakit sapu (fitoplasma), vektor, dan gejala yang muncul pada tanaman uji. Hasil deteksi keberadaan fitoplasma dengan teknik molekuler pada contoh tanaman dan wereng daun sesuai dengan uji penularan.

Gejala penyakit yang muncul pada perlakuan yang menggunakan serangga penular O. argentatus 1 ekor, 3 ekor, 5 ekor, dan 7 ekor per tanaman berasosiasi dengan fitoplasma. Hal ini membuktikan bahwa $O$. argentatus merupakan vektor dari fitoplasma. Empoasca sp. bukan merupakan vektor dari fitoplasma karena gejala penyakit sapu tidak muncul pada tanaman uji hasil penularan dengan Empoasca sp. dan tidak berasosiasi dengan fitoplasma berdasarkan hasil deteksi secara molekuler.

Menurut Bertamini et al. (2002) dan Christensen et al. (2005) infeksi fitoplasma dapat mengganggu proses fisiologi dan biokimia, seperti translokasi fotosintat sehingga menyebabkan gangguan fisiologi berupa terganggunya keseimbangan hormon yang mengakibatkan munculnya gejala proliferasi, filodi, dan virescens. 
Fitoplasma tidak dapat dibiakkan secara in vitro pada medium buatan maka cara mendeteksi fitoplasma menjadi sangat bergantung pada teknik molekuler, seperti PCR yang menggunakan DNA sebagai target deteksi. Teknik ini dapat digunakan untuk mendeteksi fitoplasma yang berada dalam jaringan tanaman dengan akurat karena bersifat sangat sensitif, hanya dengan satu molekul DNA saja maka proses amplifikasi sudah dapat terjadi (Marcone et al. 1997; Galetto dan Marzachi 2010). Ketersediaan cetakan DNA yang memiliki kualitas baik sangat penting dalam teknik PCR. Menurut Marzachi et al. (2004) keberhasilan teknik PCR sangat bergantung pada metode yang digunakan dalam mendapatkan DNA yang berkualitas baik. Beberapa teknik molekuler lain yang juga dapat digunakan untuk mendeteksi fitoplasma adalah nested PCR, analisis randomly fragment length polymorphism (RFLP) (Lee et al. 2004; Sertkaya et al.2007). Berdasarkan pada uji penularan dan deteksi fitoplasma dengan teknik PCR, diketahui bahwa wereng daun yang berada pada pertanaman kacang tanah dan memiliki kemampuan menularkan fitoplasma penyebab penyakit sapu hanya spesies O. argentatus. Menurut Nielson (1968) dan Christensen et al. (2005), fitoplasma dan serangga vektor memiliki hubungan yang spesifik, artinya bahwa suatu spesies serangga hanya menularkan satu jenis fitoplasma.

\section{DAFTAR PUSTAKA}

Bertaccini A, Duduk B. 2009. Phytoplasma and phytoplasma diseases: a review of recent research. Phytopathol Mediterr. 48:355-378.

Bertamini M, Nedunchezhian N. 2002. Phytoplasma [Stolbur-subgroup (Bois Noir-BN)] infection inhibits photosynthetic pigments, ribulose-1,5-bisphosphate carboxylase and photosynthetic activities in field grown grapevine (Vitis vinifera L. cv. Chardonnay) leaves. Physiol Mol Plant Pathol. 61(6):357-366. DOI: http://dx.doi. org/10.1006/pmpp.2003.0449.
Christensen NM, Axelsen KB, Nicolaisen M, Schulz A. 2005. Phytoplasmas and their interactions with hosts. Trends Plant Sci. 10(11):526-535. DOI: http://dx.doi. org/10.1016/j.tplants.2005.09.008.

D’Arcy CJ, NaultLR. 1982. Insect transmission of plant viruses and mycoplasma like and rickettsia like organisms. Plant Dis. 66:99104. DOI: http://dx.doi.org/10.1094/PD66-99.

Deng S, Hiruki C. 1991. Amplification of 16S rRNA genes from culturable and nonculturable mollicutes. J Microbiol Methods. 14(1):53-61. DOI: http://dx.doi. org/10.1016/0167-7012(91)90007-D.

Dellaporta SL, Wood J, Hicks JB. 1983. A plant DNA minipreparation: version II. Plant Mol Biol Rep. 1(4):19-21. DOI: http://dx.doi.org/10.1007/BF02712670.

Galetto L, Marzachi C. 2010. Real-time PCR diagnosis and quantification of phytoplasma. Di dalam: Weintraub PG, Jones P, editor. Phytoplasma Genomes, Plant Hosts and Vector. Preston (UK): MPG Books Group. hlm 1-18.

Goodwin PH, Xue BG, Kuske CR, Sears MK. 1994. Amplification of plasmid DNA to detect plant pathogenic mycoplasmalike organism. Ann Appl Biol. 124(1):27-36. DOI: http://dx.doi. org/10.1111/j.1744-7348.1994.tb04112.x.

Iwaki M. 1978. Identity of mycoplasmalike agents of legume witches broom in Indonesia. CRIA Bogor. 41:1-11.

Lee IM, Martini M, Marcone C, Hu SF. 2004. Classification of phytoplasma strains in the elm yellows group (16SrV) and proposal of 'Candidatus Phytoplasma ulmi' for the phytoplasma associated with elm yellows. J Syst Evol Microbiol. 54:337-347. DOI: http://dx.doi.org/10.1099/ijs.0.02697-0.

Marcone C, Ragozzino A, Seemuller E. 1997. Detection of bermuda grass white leaf disease in Italy and characterization of the associated phytoplasma by RFLP analysis. Plant Dis. 81(8):862-866. DOI: http:// dx.doi.org/10.1094/PDIS.1997.81.8.862. 
Marzachi C, Milne RG, Bosco D. 2004. Phytoplasma-plant-vector relationships. Di dalam: Pandalai SG, Gayathri A, editor. Recent Research Development in Plant Pathology. Kerala (IN): Research Signpost. hlm 211-241.

McCoy RE, Tsai JH, Norris RC, Gwin GH. 1983. Pigeon pea witches' broom in Florida. Plant Dis. 67:443-445. DOI: http://dx.doi.org/10.1094/PD-67-443.

Nielson MW. 1968. The Leafhopper Vectors of Phytopathogenic Viruses (Homoptera: Cicadellidae) Taxonomy, Biology and Virus Transmission. Washington (US): Dep. Agric Tech Bull.

Nugroho S, Suseno R, Hidayat SH, Hidayat P. 2000. Evaluasi ketahanan beberapa varietas kacang tanah terhadap fitoplasma. Bul HPT. 12(2):48-52.

Přibylová, Špak J. 2013. Dodder transmission of phytoplasmas. Methods Mol Biol. 938:4146. DOI: http://dx.doi.org/10.1007/978-162703-089-2_4.

Schneider BE, Seemuller CD, Smart BC, Kirkpatrick. 1995. Phylogenetic classification of plant pathogenic mycoplasma like organisms or phytoplasma. Di dalam: Razin S, Tully JG, editor. Molecular and
Diagnostic procedures in Mycoplasmology. Volume ke-1. London (UK): Academic Pr. Sertkaya G, Martini M, Musetti R, Osler R. 2007. Detection and molecular characterization of phytoplasmas infecting sesame and solanaceous crops in Turkey. Bull Insectol. 60(2):141-142.

Smart CD, Schneider B, Blomquist CL, Guerra LJ, Harisson NA, Ahrens U, Lorenz KH, Seemuller E, Kirkpatrick BC. 1996. Phytoplasma-specific PCR primers based on sequences of the 16S-23S rRNA spacer region. Appl Environ Microbiol. 62(8):2988-2993.

Weintraub PG. 2007. Insect vectors of phytoplasmas and their control an update. Bull Insectol. 60(2):169-173.

WeintraubPG, Beanland L. 2006. Insectvectors of phytoplasmas. Annu Rev Entomol. 51:1-111. DOI: http://dx.doi.org/10.1146/ annurev.ento.51.110104.151039.

Wongkaew P, Fletcher J. 2004. Sugarcane white leaf phytoplasma in tissue culture: long-term maintenance, transmission, and oxytetracycline remission. Plant Cell Rep. 23:426-434. DOI: http://dx.doi. org/10.1007/s00299-004-0847-2. 